Article

\title{
Seeing Green: The Re-discovery of Plants and Nature's Wisdom
}

\section{Monica Gagliano}

Centre for Evolutionary Biology, The University of Western Australia, 35 Stirling Hwy, Crawley, Western Australia 6009, Australia; E-Mail: monica.gagliano@uwa.edu.au

Received: 17 February 2013; in revised form: 7 March 2013 / Accepted: 11 March 2013 /

Published: 15 March 2013

\begin{abstract}
In this article, I endeavor to recount the odd history of how we have come to perceive plants like we do, and illustrate how plants themselves perceive and sense the world and, most importantly, what they can tell us about Nature. Through examples of the ingenious ways plants have evolved to thrive, I engage the idea that our modern society is afflicted by a severe disorder known as plant blindness, a pervasive condition inherited from our forefather Aristotle and accountable for the current state of vegetal disregard and hence environmental dilapidation. I propose that the solution to this state of affairs rests in a radical change of perspective, one that brings the prevailing, yet defective, Aristotelian paradigm together with its expectations on how Nature should behave to an end. Enacted, such change releases us into a new experience of reality, where the coherent nature of Nature is revealed.
\end{abstract}

Keywords: plant blindness; coherence; cooperation; facilitation; competition; plant behavior; sensing

\section{Sensing the World through Historical Deviations}

We have to remember that what we observe is not nature in itself, but nature exposed to our method of questioning.

—Theoretical physicist and philosopher Werner Heisenberg [1]

Everything any living organism knows about the world comes to it through its senses. Such a deceptively simple task bears the most crucial challenge all living organisms are confronted with-the requirement to evolve and use numerous signal-transduction systems (i.e., stimulus-response pathways; [2]) to sense the surrounding environment and ensure the most appropriate adaptive responses in order to survive and proliferate in a range of biological niches. By definition then, all 
living organisms are intrinsically sensitive creatures and it would seem truly oxymoronic to define anything alive as insensitive. Yet, this is how vegetal life has been and generally still is regardedpassive and insensitive. Clearly, this is very far from the truth, but the idea is so deeply rooted in our thought and taken as an unquestioned reality that it still misinforms our way of thinking about plants today. By revealing its historical origins, the complacent attitude we hold toward plants becomes undeniably challenged and no longer excusable.

The earliest Greek philosophers such as Empedocles (495-435 BCE) and Anaxagoras (500-428 BCE) and later, Plato (427-347 BCE) believed that plants, like animals, were sensitive organisms [3,4]. It was Aristotle (384-322 BCE) who first positioned plants outside of the sensitive life domain and used plant insensitivity as the key criterion to differentiate between plants and animals [3,5]. Aristotle's zoocentric perspective of the sensorial world and thus his 'default position of plant exclusion' ([6], p. 37) had a profound and long-lasting influence on virtually everyone who came after him, ultimately fathering the Western paradigm of modern science. Ironically, however, the Father of Science was no scientist himself as he was interested in postulating rather than experimentally testing his ideas. And specifically in regards to plants, we had to wait until the $17^{\text {th }}$ century for experimental botanists to start recognizing some fallacy in his fundamental assumption.

\section{Aristotelian False Premises on the Enlightened Behavior of Plants: The Case of Phototropism}

Be like the flower, turn your faces to the sun.

—Poet, artist and writer Kahlil Gibran (1883-1931)

Plants are renowned for feasting on the radiant energy of the sun to photosynthesize, the process by which they convert light into food to nourish themselves and sustain life on Earth. This is so much so that to ensure that as much light as possible is captured for photosynthesis, plants move and orient their leaves and stems towards the light through a complex interaction of photoreceptors, hormones and signaling pathways. This purposeful solar-tracking behavior is phototropism. Plant phototropic behavior is so widespread and obvious that, of course, it had already been observed and recorded at the time of Aristotle by one of his own pupils, Theophrastus of Eresus (371-285 BCE). However and despite his own observations of the phototropic behavior in many different plant species, Theophrastus blindly subscribed to the Aristotelian belief of plant passivity and insensitivity; he described plant phototropism by implicating the activity of the sun as the physical external agent removing fluid from the illuminated side of the plant to cause such directional movement of leaves and stems.

While such an explanation for the active behavior by which plants track light may cause some laughter today, the Aristotelian dogma was stubbornly maintained till the $17^{\text {th }}$ century when plants were finally bestowed with some level of sensitivity. The experimental botanist Sir Thomas Browne (1605-1682) was amongst the first to note that shoots were attracted and grew toward the sun, hence providing the scientific basis for the establishment of a theory of plant sensitivity.

"And large fields of Vegetables are able to maintain their verdure at the bottome and shady part of the Sea; yet the greatest number are not content without the actual rayes of the Sunne, but bend, incline and follow them; as large lists of solisequious or Sun-following plants” ([7], p. 106) 
Because of his personal observations of a wide range of plant movements, Browne had no problem in accepting the concept of plant sensitivity, but he never proposed it openly in his scientific writings. We have to wait yet another century for the idea that plants sense light to receive wider acceptance, albeit plant movements are still described as purely mechanical consequences of growth [8]. Interestingly, Henri Dutrochet (1776-1843) had already proposed that phototropism was an endogenous response of plants to light [9], but it was not until the $19^{\text {th }}$ century that Julius von Weisner (1838-1919) finally demonstrated the inductive nature of the response [10] and Charles Darwin (1809-1882) postulated that a substance produced in the shoot tip of a seedling must induce the curvature in the lower regions of the plant, such that the bending response occurs [11]. In the following century, the 'substance' Darwin thought was implicated in the phototropic response was eventually discovered by Frits Went (1863-1932) as the first plant hormone, auxin [12]. By the time World War II was over, we had learnt that plants were not only capable of detecting light, but also 'seeing' its different colors (through photoreceptors known as phytochromes; reviewed in [13]), and even measure how much light they received each day (i.e., photoperiodism; see [14]).

It is astonishing to think that millennia have elapsed between the times of Aristotle and the present day and yet, plants are still generally considered to be passive and insensitive organisms, or, worse, simply not important. Even Nature, arguably the most prestigious of all scientific journals, forgot the plants when compiling a resource aimed at the wider general public and intended to explain the empirical evidence for the process of evolution by natural selection in 2009 (see [15]). I would argue that this exemplifies a widespread and very significant problem. As pointed out by Wandersee and Schussler [16] 'the misguided, anthropocentric ranking of plants as inferior to animals, leading to the erroneous conclusion that they are unworthy of human consideration' shapes a society that pays no attention to plants, whose fundamental role is to ensure continuity of life on Earth. How can any society recognize that plant conservation is one of humanity's most crucial issues, when it literally cannot 'see' plants? To start treating this affliction known as plant blindness [17], the broken Aristotelian spectacles we are wearing must be removed and the worldview we are subscribing to must be re-considered. If anything, history has clearly demonstrated that our current plant-less view of the world is based on an ancient misconception-one that is plainly incorrect. This claim is no metaphysical conjecture; instead it is born out by the available evidence that plants, like all living organisms, are very sensitive and active, monitoring and integrating lots of parameters from their environment and using numerous signaling systems to sense, assess, respond and even facilitate each other by actively acquiring information from their surroundings. In the following paragraphs, I will offer examples illustrating how extraordinary the complexity of plant behaviour truly is and how this understanding makes it very easy for us to 'see' plants.

\section{A Plant's Perspective of the World, and What It Has to Say about It!}

\subsection{A Plant's-Eye View of the World}

Think about this: plants see you. 
Humans may fail to notice plants and overlook their importance to one's daily life, yet plants see us very clearly. Naturally, plants (like animals) need to be aware of the visual environment around them in order to survive and light signals provide important information of ecological value for plants to strive within their communities. Here are some examples.

Example 1. By detecting and monitoring changes in the amount of light available, its color and where it comes from within their environment, plants are able to direct their growth in response to neighbor competition. Indeed, their success within a community depends on their capacity to detect neighbors quickly and their ability to respond appropriately. Plants are able to detect specific light ratios reflected from or transmitted by their neighbors, primarily red: far-red ratios [19]. Because daylight contains approximately equal parts of red and far-red light and plants absorb red light (hence they look green to us), a drop in the red: far-red ratio is a reliable indicator of the proximity of a neighbor. By monitoring both the availability of direct sunlight in the environment and the shadows cast by others, a plant can determine if and who is growing next to it and direct its own growth to avoid being shaded (i.e., shade-avoidance syndrome, [20]).

Example 2. Plants, like animals, use light in terms of adaptive color change to attract pollinators [21]. Consider this: young and unrewarding animal-pollinated flowers and young and unripe fleshy fruits are usually green and cryptic. Specifically, flowers usually advertise their colors and become conspicuous only towards anthesis, the developmental stage when flowers open and offer nectar and pollen as rewards to pollinators. While many plants retain the conspicuous advertising colors of their flowers until these wilt, many others produce flowers that change color after they have been pollinated. A change in flower color that occurs during an inflorescence may reduce the flower's advertising intensity, and thus its detectability by pollinators. On the other hand, retaining the coloration after pollination, or after such flowers turn unreceptive, may reduce pollinator visits to unpollinated flowers in the same plant, thus diminishing the plant's overall reproductive success. By simultaneously reducing the reward after pollination and their attractiveness by changing their color, plants direct pollinators to their unpollinated flowers within the same inflorescence.

Some plants even take the color change strategies a step further. In the creeper Quisqualis indica, for example, flowers opening at dusk are oriented horizontally and are white in color to attract night pollinators such as hawkmoths. As the new day approaches, their color turns to pink and later to red and simultaneously the flower orientation changes to become pendulous, to attract day pollinators such as honeybees, flies, and sunbirds [22]. Other plants like Pseudowintera colorata turn their leaf margins red to reduce predatory attacks by signaling to herbivorous insects the presence of increased chemical defenses [23]; this is one of numerous examples of aposematic or warning coloration in plants. Yet despite the recognized evolutionary importance of warning signals in shaping relationship between species [24], it took a long time for scientists to consider plant coloration in this context and sadly, a database search of "aposematism in plants" does not yield anything earlier than the year 2001 (see [25] for a review of the topic).

\subsection{Chemical Conversations}

What's in a name? that which we call a rose by any other name would smell as sweet. 
Plants have an arsenal of toxic repellents to defend themselves from unwelcomed visitors as well as irresistible cocktails of airborne fragrances to inebriate our noses and those of many other animals (e.g., pollinators), and often, it is the same chemical cocktail (or at least the same chemical precursors) that attract pollinators and deter herbivore [26]. Over the last two decades, however, important insights into our understanding of plant ecology have confirmed that plants use chemical signals to actively communicate with each other as well as the broader neighborhood [27]. The literature is now replete with studies demonstrating how plants encode and process chemical information about their neighbors both above- as well as below-ground [28,29] and then modify their growth patterns accordingly [30,31].

Through the airborne plant-plant communication channel, for example, plants are able to signal to each other over approaching insect attacks and respond to chemical cues produced by injured neighbors before they are attacked or damaged themselves, thus allowing for pre-emptive defensive responses [32-34]. Similarly, when attacked, plants can produce volatiles that attract carnivorous enemies of the attacking herbivores, a syndrome known as “crying for help” [35]. Many plants also have extensive root grafting (that happens when trunks, branches or roots of two plants make contact and start growing together) which allows them to transmit signals between individuals and between species via their own anastomosed vascular system [36]. Moreover, through the release of chemical exudates in the ground and often with the facilitation of their fungal associates [37], plants can exchange information to recognize and even prevent costly competitive interactions with relatives [38,39], thereby facilitating kin selection processes such as cooperation and altruism [40], a process akin to that seen in animal social systems.

\subsection{A Philharmonic Orchestra in the Woods}

"O Tiger-lily," said Alice, addressing herself to one that was waving gracefully about in the wind, "I wish you could talk!”

"We can talk,” said the Tiger-lily: "when there's anybody worth talking to.”

Alice was so astonished that she could not speak for a minute: it quite seemed to take her breath away. At length, as the Tiger-lily only went on waving about, she spoke again, in a timid voice-almost in a whisper.

"And can all the flowers talk?”

"As well as you can,” said the Tiger-lily. "And a great deal louder.”

—From Through the Looking Glass by Lewis Carroll (1832-1898)

Plants have evolved to detect and respond to sound waves or vibrations in their environment. In fact, the ability of plants to respond to vibrations is more widespread than we think and numerous species have evolved a range of adaptive strategies to exploit sound. For example, some 20,000 species use buzz pollination where the pollen is released from flowers only when they are vibrated at the correct sound frequency, a feat achieved by bees that have co-evolved to vibrate their flight muscles appropriately [41]. Despite the ecological and evolutionary significance of sound in plant-animal interactions and several studies over the last two decades pointing to the phenomenological importance of acoustic vibrations in plant physiology (see [42] for a review of the topic), no quantitative information on the ability of plants to detect and respond to sound, and modify their growth accordingly, was available until very recently [43]. Specifically, preliminary investigations of both 
emission and detection of sound by plants clearly indicate that they have the ability to detect acoustic vibrations and exhibit frequency-selective sensitivity (i.e., plants respond to the same range of frequencies that they emit themselves) that generates behavioral modifications.

Given the speed and ease with which it transmits through the environment, especially in dense substrates like soil, sound offers a particularly effective transmission channel for both short and long range signaling. For short range, it could possibly be involved in modulating the swarm behavior of growing roots [44]. For long range signaling, other functions related to resource finding, intra- and/or interspecific competition or cooperation, and growth orientation and coordination within the substrate can easily be envisaged. All of these potentially adaptive functions of sound in the life of plants are yet to be explored. One way to begin the exploration of acoustic communication in plants is to examine sound in plants at the proximate level—what are the mechanisms underlying how plants do all these feats? At this stage, this answer remains elusive, but ideas and proposals to explain how plants produce sound are starting to emerge [42,45]. Clearly, we are not expecting plants to possess the specialized morphological structures and/or organs that animals have evolved to produce sound; however, it is possible that the biophysical principles at the cellular and molecular level may not be so dissimilar across all eukaryotes. This would involve considering that sound waves are generated by objects that vibrate and cells and their components in all eukaryotes vibrate as a result of intracellular motions generated by cellular processes such as the activity of motor proteins and the cytoskeleton. Yet how can the nanovibration of a tiny cell translate into a sizable acoustic emission in a whole plant? Because cells are imbedded in a tissue and hence surrounded by other cells, individual cells are affected by the mechanical property of neighboring ones and this eventually builds up into a collective 'in-tune' mode (i.e., coherent excitation, [46]) and results in the amplification of the signal. Actually, nanomechanical oscillations of various components in the cytoskeleton within cells alone can generate a spectrum of coherent vibrations spanning from low $\mathrm{KHz}$ up to $\mathrm{GHz}[46,47]$.

Coherent processes belong to a new way of looking at and understanding the reality of the world. This is largely the domain of quantum physics, but it seems that plants may provide an ideal starting model to develop an equivalent quantum domain in biology. In fact, the existence of coherent, non-localized phenomena has been previously reported in plants (e.g., quantum coherence in marine algae photosynthesis, [48]) and such an approach may be required and prove fruitful in understanding plant bioacoustics. Beyond its importance in plant biology and within the life sciences, I propose that coherence is a fundamental concept to assist us in rethinking the vegetal and reconnecting us to Nature. The paragraphs to follow explain and aim at exploring the significant shift in paradigms this concept calls for.

\section{Taking Plants Seriously: Lessons on the Nature of All Things}

With its glorious nonhuman past and its uncertain but provocative future, this life, our life, is embedded now, as it always has been, in the rest of Earth's sentient symphony.

—From What is life? by Lynn Margulis and Dorion Sagan [49]

The concept of coherence is used in a variety of contexts and has been widely adopted by disciplines as diverse as linguistics, philosophy, economics, cognitive science, mathematics and physics. In physics, for example, coherence refers to a fundamental principle of a quantum field, a 
domain within which atoms and molecules are in sync with each others moving exactly together in space and time; in linguistics, it describes the cohesive links within a sentence that hold the text together and give it meaning. Evidently no matter the context, coherence is a term that implies some form of collective association within systems and among systems (as well as across systems or subsystems) in which individual units interact by connecting closely together (from the Latin word cohaereō - to cling together, to be closely connected with, to be in harmony).

In plants, we have now learnt that collective associations are indeed an ecologically common state of affairs. It has become increasingly recognised that facilitative interactions amongst plants are ubiquitous [50] and the influence of facilitation is an important element in regulating the composition and diversity of whole plant communities [51-53]. Indeed, many plants literally 'help' each other [54,55] by improving growth [56], fixing nitrogen [57], nurse cropping [58], controlling pests [59] or attracting beneficial organisms such as insects [60] or mycorrhizae [61,62]. Similarly but at the deeper level of function, coherent processes in plants underpin the capacity for photosynthesis [48] and possibly sound production [42]. Moreover, a closer look into the nature of all things reveals that such collective 'in tune' behaviour is in fact an essential aspect of life in general and so ubiquitous that it is found at all levels of biological organization from the assembly of eukaryotic cell that relies on the symbiotic cooperation of its internal organelles [63] to the evolution of multicellular organisms [64] and ultimately organismal colonies and societies as we know them for many animal species including humans [65]. Interestingly, the best insights into the process of how single-celled organisms may have evolved into simple (e.g., colonial) and then later more complex multicellular forms through communication and collaborative effort amongst cells have, in fact, been offered by plant phylogenies, where the emergence of multicellularity in the three major clades has occurred, at least, six separate times [66]. So it seems that cooperation, the process of acting and working together in a coherent mode, is far from being a rare trait and despite the general idea that biological evolution is the outcome of fierce competition among selfish parties, the evidence indicates that, paradoxically, the very competitive evolutionary process of natural selection involves cooperation [67]. It is becoming clearer that the complex web of life is a system built on minimal conflict and instead substantial cooperation among lower-level units to evolve into higher-level units; in fact, it is through the evolution of new levels of organization, when the competing units at the lower level begin to work together, that cooperation allows specialization and promotes biological diversity [65].

From our well-established view of the Aristotelian world of false dichotomies, the idea that two mutually exclusive possibilities, like cooperation and competition, can coexist and, most importantly, make sense in the light of evolution may seem, indeed, paradoxical. This myopia is reinforced by the misuse of concepts like 'survival of the fittest' as a synonym for the process of natural selection through competition. And in fact, the notion that neighbouring species negatively impact on one another through competitive interactions has long been the key component of many classic ecological theories and is still a prevailing view in plant ecology, in particular. However this is not exactly what we actually see occurring in Nature and there is little evidence supporting the idea that competition has been the driving force in the evolution of species [68]. This brief exploration into the world of plants aimed at offering this 'alternative' perspective on the nature of plants (which clearly are anything but insensitive) as well as the nature of Nature (coherence and cooperative interactions amongst apparently competing parts—whether microbial, vegetal or animal—make Nature's fabrics). As demonstrated 
here, plants are a most precious source of insights about the way Nature works and offer the most exquisite examples of coherence in Nature, from the finer and mostly invisible details of photosynthetic processes stretching out to the ecological and evolutionary processes at the macro scales. It is clear, then, that our blindness towards these organisms is no longer excusable.

\section{Acknowledgments}

This study was supported by Research Fellowships from the University of Western Australia and the Australian Research Council. The author thanks Root Gorelick, Mihail Tomescu and one anonymous reviewer for their constructive comments on an earlier version of the manuscript.

\section{References and Notes}

1. Heisenberg, W. Physics and Philosophy: The Revolution in Modern Science; Harper \& Row: New York, NY, USA, 1958.

2. Clark, G.B.; Thompson, G., Jr.; Roux, S.J. Signal transduction mechanisms in plants: An overview. Curr. Sci. 2001, 80, 170-177.

3. Damascenus, N. Nicolaus Damascenus de Plantis: Five Translations; Drossaart Lulofs, H.J., Poortman, E.L.J., Eds.; North-Holland: New York, NY, USA, 1989.

4. Shemp, J. Plants in Plato's Timaeus. Class. Q. 1947, 41, 53-60.

5. McKeon, R. Introduction to Aristotle; The Modern Library: New York, NY, USA, 1947.

6. Hall, M. Plants as Persons: A Philosophical Botany; SUNY Press: Albany, NY, USA, 2011.

7. Browne, T. The Garden of Cyrus. In The Works of Sir Thomas Browne: Miscellany Tracts, Repertorium, Miscellaneous Writings; Keynes, G., Ed.; Faber and Gwyer: London, UK, 1931; Volume 4.

8. de Candolle, A.P. Physiologie Végétale; Béchet: Paris, France, 1832.

9. Dutrochet, H. Recherches Anatomiques et Physiologiques sur la Structure Intime des Animaux et des Végétaux et sur Leur Motilité; J.-B. Bailliére: Paris, France, 1824.

10. von Wiesner, J. Die heliotropischen erscheinungen im pflanzenreiche: Eine physiologische monographie; Kaiserlich-königlichen Hof- und Staatsdruckerei: Wien, Germany, 1878.

11. Darwin, C. The Power of Movement in Plants; John Murray Publishers: London, UK, 1880.

12. Went, F.W. Die Erklarung des phototropischen krummungsverlaufs. Recueil des Travaux Botaniques Neerlandais 1928, 25, 483-489.

13. Smith, H. Phytochromes and light signal perception by plants-An emerging synthesis. Nature 2000, 407, 585-591.

14. Whyte, R.O.; Oljhovikov, M.A. Photoperiodism in the plant kingdom. Nature 1939, 143, 301-302.

15. Tomescu, A.M.F. Evolutionary gems of the plant world shine just as brightly. Nature 2009, 457, 596.

16. Wandersee, J.H.; Schussler, E.E. A model of plant blindness. Poster and paper presented at the 3rd Annual Associates Meeting of the 15 Laboratory, Louisiana State University, Baton Rouge, LA, USA, 1998.

17. Wandersee, J.H.; Schussler, E.E. Preventing plant blindness. Am. Biol. Teach. 1999, 61, 82-86. 
18. Chamowitz, D. What a Plant Knows: A Field Guide to the Senses of Your Garden-and beyond; Farrar, Straus \& Giroux: Oxford, UK, 2012.

19. Ballaré, C.L.; Sánchez, R.A.; Scopel, A.L.; Casal, J.J.; Ghersa, C.M. Early detection of neighbour plants by phytochrome perception of spectral changes in reflected sunlight. Plant Cell Environ. 1987, 10, 551-557.

20. Smith, H. Physiological and ecological function within the phytochrome family. Annu. Rev. Plant Physiol. Plant Mol. Biol. 1995, 46, 289-315.

21. Willmer, P.; Stanley, D.A.; Steijven, K.; Matthews, I.M.; Nuttman, C.V. Bidirectional flower color and shape changes allow a second opportunity for pollination. Curr. Biol. 2009, 19, 919-923.

22. Eisikowitch, D.; Rotem, R. Flower orientation and color change in Quisqualis indica and their possible role in pollinator partitioning. Botan. Gaz. 1987, 148, 175-179

23. Cooney, L.J.; Van Klink, J.W.; Hughes, N.M.; Perry, N.B.; Schaefer, H.M.; Menzies, I.J.; Gould, K.S. Red leaf margins indicate increased polygodial content and function as visual signals to reduce herbivory in Pseudowintera colorata. New Phytol. 2012, 194, 488-497.

24. Ruxton, G.D.; Sherratt, T.N.; Speed, M.P. Avoiding Attack: The Evolutionary Ecology of cRypsis, Warning Signals and Mimicry; Oxford University Press: Oxford, UK, 2004.

25. Lev-Yadun, S. Aposematic (warning) coloration in plants. In Plant-environment interactions. From Sensory Plant Biology to Active Plant Behavior; Baluska, F, Ed.; Springer-Verlag: Berlin, Germany, 2009; pp. 167-202.

26. Pellmyr, O.; Tang, W.; Groth, I.; Bergstrom, G.; Thien, L.B. Cycad cone and angiosperm floral volatiles: Inferences for the evolution of insect pollination. Biochem. Syst. Ecol. 1991, 19, 623-627.

27. Heil, M.; Karban, R. Explaining evolution of plant communication by airborne signals. Trends Ecol. Evol. 2010, 25, 137-144.

28. Mahall, B.E.; Callaway, R.M. Root communication among desert shrubs. P. Natl. Acad. Sci. USA 1991, 88, 874-876.

29. Mahall, B.E.; Callaway, R.M. Root communication mechanisms and intracommunity distributions of two Mojave Desert shrubs. Ecology 1992, 73, 2145-2151.

30. Trewavas, A. Aspects of Plant Intelligence. Ann. Bot. 2003, 92, 1-20.

31. Baluška, F.; Mancuso, S. Plant neurobiology as a paradigm shift not only in the plant sciences. Plant Signal. Behav. 2007, 2, 205-207.

32. Paré, P.W.; Tumlinson, J.H. Plant volatiles as a defense against insect herbivores. Plant Physiol. 1999, 121, 325-331.

33. Karban, R.; Baldwin, I.T.; Baxter, K.J.; Laue, G.; Felton, G.W. Communication between plants: Induced resistance in wild tobacco plants following clipping of neighboring sagebrush. Oecologia 2000, 125, 66-71.

34. Heil, M.; Ton, J. Long-distance signalling in plant defence. Trends Plant Sci. 2008, 13, 264-272.

35. Dicke, M. Behavioural and community ecology of plants that cry for help. Plant Cell Environ. 2009, 32, 654-665.

36. Tarroux, E.; DesRochers, A. Effects of natural root grafting on growth response of jack pine (Pinus Banksiana; Pinaceae). Am. J. Bot. 2011, 98, 967-974.

37. Whitfield, J. Underground networking. Nature 2007, 449, 136-138.

38. Dudley, S.A.; File, A.L. Kin recognition in an annual plant. Biol. Lett. 2007, 3, 435-438. 
39. Murphy, G.P.; Dudley, S.A. Kin recognition: Competition and cooperation in Impatiens (Balsaminaceae). Am. J. Bot. 2009, 96, 1990-1996.

40. Karban, R.; Shiojiri, K.; Ishizaki, S.; Wetzel, W.C.; Evans, R.Y. Kin recognition affects plant communication and defence. Proc. R. Soc. B 2013, 280, doi: 10.1098/rspb.2012.3062.

41. Proctor, M.; Yeo, P.; Lack, A. The Natural History of Pollination; Timber Press: Portland, OR, USA, 1996.

42. Gagliano, M. Green symphonies: A call for studies on acoustic communication in plants. Behav. Ecol. 2012, doi: 10.1093/beheco/ars206.

43. Gagliano, M.; Mancuso, S.; Robert, D. Towards understanding plant bioacoustics. Trends Plant Sci. 2012, 17, 323-325.

44. Ciszak, M.; Comparini, D.; Mazzolai, B.; Baluska, F.; Arecchi, F.T.; Vicsek, T.; Mancuso, S. Swarming behavior in plant roots. PLoS ONE 2012, 7, e29759.

45. Gagliano, M.; Renton, M.; Duvdevani, N.; Timmins, M.; Mancuso, S. Acoustic and magnetic communication in plants: Is it possible? Plant Signal. Behav. 2012, 7, 1346-1348.

46. Pokorný, J. Conditions for coherent vibrations in the cytoskeleton. Bioelectrochem. Bioenerg. 1999, 48, 267-271.

47. Pokorný, J.; Jelínek, F.; Trkal, V.; Lamprecht, I.; Hölzel, R. Vibrations in microtubules. J. Biol. Phys. 1997, 23, 171-179.

48. Collini, E.; Wong, C.Y.; Wilk, K.E.; Curmi, P.M.G.; Brumer, P.; Scholes, G.D. Coherently wired light-harvesting in photosynthetic marine algae at ambient temperature. Nature 2010, 463, 644-647

49. Margulis, L.; Sagan, D. What is life? University of California Press: Berkeley, CA, USA, 2000.

50. Valiente-Banuet, A.; Rumebe, A.V.; Verdú, M; Callaway, R.M. Modern Quaternary plant lineages promote diversity through facilitation of ancient Tertiary lineages. P. Natl. Acad. Sci. USA 2006, 103, 16812-16817.

51. Brooker, R.W. Plant-Plant interactions and environmental change. New Phytol. 2006, 171, 271-284.

52. Callaway, R.M. Positive Interactions and Interdependence in Plant Communities; Springer: Dordrecht, The Neatherlands, 2007.

53. Brooker, R.W.; Maestre, F.T.; Callaway, R.M.; Lortie, C.L.; Cavieres, L.A.; Kunstler, G.; Liancourt, P.; Tielbörger, K.; Travis, J.M.J.; Anthelme, F.; et al. Facilitation in plant communities: The past, the present, and the future. J. Ecol. 2008, 96, 18-34.

54. Callaway, R.M. Positive interactions among plants. Bot. Rev. 1995, 61, 306-349.

55. Bruno, J.F.; Stachowicz, J.J.; Bertness, M.D. Inclusion of facilitation into ecological theory. Trends Ecol. Evol. 2003, 18, 119-125.

56. Plath, M.; Mody, K.; Potvin, C.; Dorn, S. Do multipurpose companion trees affect high value timber trees in a silvopastoral plantation system? Agroforest. Syst. 2011, 81, 79-92.

57. Fustec, J.; Lesuffleur, F.; Mahieu, S.; Cliquet, J.-B. Nitrogen rhizodeposition of legumes. A review. Agron. Sustain. Dev. 2010, 30, 57-66.

58. Liphadzi, K.B.; Reinhardt, C.F. Using companion plants to assist Pinus patula establishment on former agricultural lands. S. Afr. J. Bot. 2006, 72, 403-408.

59. Morley, K.; Finch, S.; Collier, R.H. Companion planting-Behaviour of the cabbage root fly on host plants and non-host plants. Entomol. Exp. Appl. 2005, 117, 15-25. 
60. Landis, D.A.; Wratten, S.D.; Gurr, G.M. Habitat management to conserve natural enemies of arthropod pests in agriculture. Annu. Rev. Entomol. 2000, 45, 175-201.

61. Casanova-Katny, M.A.; Torres-Mellado, G.; Palfner, G.; Cavieres, L. The best for the guest: High Andean nurse cushions of Azorella madreporica enhance arbuscular mycorrhizal status in associated plant species. Mycorrhiza 2011, 21, 613-622.

62. Montesinos-Navarro, A.; Segarra-Moragues, J.G.; Valiente-Banuet, A.; Verdú, M. Plant facilitation occurs between species differing in their associated arbuscular mycorrhizal fungi. New Phytol. 2012, 196, 835-844.

63. Sagan, L. On the origin of mitosing cells. J. Theor. Biol. 1967, 14, 225-193.

64. Maynard-Smith, J.; Szathmáry, E. The Major Transitions in Evolution; Oxford University Press: Oxford, UK, 1995.

65. Strassmann, J.E.; Queller, D.C.; Avise, J.C.; Ayala, F.J. In the light of evolution V: Cooperation and conflict. P. Natl. Acad. Sci. USA 2011, 108, 10787-10791.

66. Niklas, K.J.; Newman, S.A. The origin of multicellular organisms. Evol. Dev. 2013, 15, 41-52.

67. Bateson, P. The biological evolution of cooperation and trust. In Trust: Making and Breaking Cooperative Relations; Gambetta, D., Ed.; Blackwell: Oxford, UK, 1998; pp. 14-30.

68. Sahney, S.; Benton, M.J.; Ferry, P.A. Links between global taxonomic diversity, ecological diversity and the expansion of vertebrates on land. Biol. Lett. 2010, 6, 544-547.

(C) 2013 by the author; licensee MDPI, Basel, Switzerland. This article is an open access article distributed under the terms and conditions of the Creative Commons Attribution license (http://creativecommons.org/licenses/by/3.0/). 